IJPPM

60,2

152

Received September 2009

Revised January 2010,

March 2010

Accepted March 2010

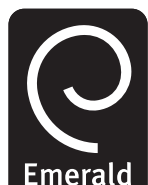

International Journal of Productivity and Performance Management Vol. 60 No. 2, 2011

pp. $152-184$

(C) Emerald Group Publishing Limited 1741-0401

DOI $10.1108 / 17410401111101485$

\section{Development of a design performance measurement matrix for improving collaborative design during a design process

\author{
Yuanyuan Yin
} \\ Winchester School of Art, University of Southampton, UK, and \\ Shengfeng Qin and Ray Holland \\ School of Engineering and Design, Brunel University, UK}

\begin{abstract}
Purpose - The purpose of this paper is to investigate how to measure collaborative design performance and, in turn, improve the final design output during a design process, with a clear objective to develop a design performance measurement (DPM) matrix to measure design project team members' design collaboration performances.

Design/methodology/approach - The methodology adopted in this research uses critical literature reviews, in-depth focus group interviews and a questionnaire survey.

Findings - The main finding of this study is a DPM matrix that addresses five DPM indicators: efficiency, effectiveness, collaboration, management skill, and innovation, and 25 detailed DPM criteria. It was found that decision-making efficiency is the most important DPM criterion for collaborative design efficiency; plus delivering to the brief for effectiveness; clear team goal/objectives for collaboration; decision-making ability for management skill; and competitive advantage for innovation.
\end{abstract}

Research limitations/implications - As the present study was focused on exploring DPM during a design process, some key DPM criteria which are not measurable during a design development process were not included in this study. The proposed multi-feedback approach for DPM matrix implementation needs to be validated in future research.

Practical implications - The DPM matrix can be applied to support a design manager in measuring and improving collaborative design performance during a design process, by reviewing and modifying collaborative design development, identifying the design team strengths and weaknesses, improving team communication, and suggesting suitable responsive actions.

Originality/value - The major contribution of this study is the investigation and development of a DPM matrix to measure collaborative design performance during a design process.

Keywords Design, Performance measures, Design management

Paper type Research paper

\section{Introduction}

Design has been recognized as one of the critical factors for business success. It contributes to promoting a business by improving customer interface with the product, enhancing product functionality, and increasing product quality (Hertenstein et al., 2005). Design is a complex process which always involves many participants from 
different disciplines to work together during the design process (Girard and Robin, 2006). Therefore, design collaboration becomes a crucial element in the design process and has a great effect on the final design performance. Consequently, a great deal of research has paid attention to improving collaborative design performance (Bstieler, 2006; Lahti et al., 2004; Qin et al., 2003). However, only a small amount of research has concentrated on increasing collaborative design performance by operating performance measurement, although it can improve design effectiveness significantly (Busseri and Palmer, 2000). Implementing an appropriate performance measurement has many advantages, such as motivating people, supporting decision-making, fostering organisational learning and continuous improvement (Chiesa et al., 2009).

Additionally, performance measurement can be operated to influence project staff's behaviour to achieve a positive business outcome (Neely et al., 2005). Thus, many companies have spent considerable time and resources redesigning and implementing performance measurement to reflect their current environment and strategies positively (Kennerley and Neely, 2003). Such a positive influence will be especially useful in the collaborative design process.

In relevant design performance measurement (DPM) research fields, many studies focused on exploring key factors of success and failure of new product development (NPD), such as market share, investment return rate, and customer feedback (Hart et al., 2003; Loch et al., 1996; Hultink and Robben, 1995). However, little research has specifically concentrated on collaborative design, especially from a design process perspective. As design process is a wide ranging research field, covering marketing, design specification, conceptual and detailed design, manufacturing, sales and after sale services and disposal, etc., the existing DPM indicators are developed based on information crossing a product development lifecycle. However, when we focus on a design process at either the conceptual or detailed design stage, the available DPM information is limited. Therefore, existing DPM indicators are not suitable for measuring collaborative design during a design process. For example, some existing DPM criteria are difficult to apply during a design process because they are highly dependant on products' after-launch information, such as market share, investment retune rate, and customers' feedback. Thus, it is still a challenge to measure and improve collaborative design during a design process based only on information typically available at design stages (TSB, 2009).

Therefore, our research aims to investigate how to measure collaborative design performance and in turn to improve the final design output during a design process, with a clear objective to develop a DPM matrix to measure design project team members' design performance. A design matrix has been selected as the format of the final research result due mainly to two reasons. First, different tools have been developed from existing DPM research such as New product development (NPD) success factors (Kušar et al., 2004; Salter and Torbett, 2003; Montoya-Weiss and Calantone, 1994), guidelines for performance measurement system design (Folan and Browne, 2005; Neely et al., 1997) and modelling of design development performance (O'Donnell and Duffy, 2002). Compared with these types of research results, a DPM matrix can provide a compact representation of collaborative design indicators, showing detailed DPM criteria for measuring collaborative design performance and associated value among the criteria tabulated in a row-column format (Sharif and 
IJPPM

60,2

154
Kayis, 2007). Furthermore, NPD success factors, guidelines or frameworks approaches generally focus on providing practical recommendations for a certain phenomenon in a single dimension. However, because of the dynamic features of collaborative design, a performance measure tool is required that can be applied in various situations during a design process (Feltham and Xie, 1994). Further, the typical format of a matrix is a structured analysis within two or more dimensions which can produce more decision supports to users for diverse circumstances, increase efficiency of DPM operation, and provide better maintenance of the DPM during a design process (Chen et al., 2002). Therefore, a DPM matrix has been selected as the format of the final research results.

There are two research questions in this study:

(1) What are key DPM indicators which can be used to demonstrate and measure collaborative design performance?

(2) What detailed criteria can be used for measuring each of the collaborative design indicators during a design process?

To answer these two research questions, literature review, focus group studies and questionnaire studies have been conducted to identify key DPM indicators and detailed DPM criteria for measuring collaborative design performance during a design process. As a result, a DPM matrix has been developed with 25 detailed DPM criteria which address five key DPM indicators: efficiency, effectiveness, collaboration, management skill, and innovation. On the one hand, the matrix can support design managers to improve collaborative design performance by evaluating design collaboration, learning from DPM results, and encouraging design team members to improve themselves during the design process. On the other hand, the matrix can also support designers to better explore their strength and weakness, and, in turn, improve design collaboration by conducting self-development. It is thus offered as a measurement and motivating tool to support collaborative design at a design stage.

This paper is structured as follows. Section 2 presents related work of collaborative design and design performance measurement research. Section 3 illustrates the overall research methodology. In sections 4 and 5, the development process and results of the DPM matrix are described. Finally, the conclusion is drawn.

\section{Related work}

Design has been regarded essentially as an application of human creativity to a purpose of creating products, services, buildings, organisations and environments which meet people's needs (Moultrie et al., 2006a; Bruce and Bessant, 2002). The complex process of integrated product design and development involves many participants from different disciplines and requires team members with various aspects of knowledge and experience to work together (adapted from Girard and Robin, 2006). Due to the complexity feature, collaborative design has been regarded as a key factor for the success of NPD and business performance (Chu et al., 2006). Collaborative design is considered as a process in which design team members actively communicate and work together in order to jointly establish design goals, search through design problem spaces, determine design constraints, and construct a design solution (Zha and Du, 2006). Numerous studies have paid attention to improving collaborative design from different perspectives in the past two decades. These studies can be divided into two categories. One is technical-based collaborative design 
research, which focuses on collaborative design supporting tools, while the other is management-based, which addresses team management and project management issues (Bstieler, 2006; Zhang et al., 2004; Tay and Roy, 2003; Chen et al., 2002). According to Busseri and Palmer (2000), collaborative design can be improved by conducting performance measurements regularly for the team functions. They concluded that conducting performance measurements through a design process can lead to higher levels of self-rated and observer-rated group effectiveness; higher levels of self-rated group satisfaction and double the number of positive comments (compared to negative comments) from team members. In other words, performance measurement actions do help in improving the design team collaboration performance.

With the rapid growth in awareness of design, DPM has attracted more attention from academia since 1990. Most of the DPM research has concentrated on exploring essential indicators for measuring the success of product design, and discovering detailed criteria for measuring these indicators, such as actual against planned time for design efficiency, delivering to the brief for design effectiveness, sharing information for design collaboration, and technology novelty for design innovation (Bart and Pujari, 2007; Hull, 2004; O'Donnell and Duffy, 2002; Chiu, 2002; Tatikonda and Montoya-Weisis, 2001; Pawar and Driva, 1999). For instance, design efficiency has been regarded as an important factor of design due to the fact that it can support companies to deliver high quality products and services on time and at a lower cost than that of their competitors (Naveh, 2005). Salomo et al. (2007) highlighted that innovation plays a critical role in building competitive advantages and can contribute significantly to a firm's growth and profitability. Regarding the detailed DPM criteria, role-taking ability, openness, communication skills, and leadership have been highlighted as key criteria for measuring effectiveness in design collaboration (Bstieler, 2006; Bond et al., 2004).

Furthermore, the existing DPM research can be classified into two categories: product-focused and process-focused (Bruce and Bessant, 2002). The former concentrates on measuring design performance based on the final product, with measurement factors such as aesthetics, novelty, function, integrity, reliability, and longevity. The latter focuses on measuring design performance derived from the design development process with measurement factors, such as time, cost, effectiveness, communication, and fitness for the design purpose. For example, Moultrie et al. (2006b) developed a product-focused design audit tool, which provided design checklists regarding novelty, desirability, usability, and producibility, to assess perceptions towards product characteristics, while the others (Maier et al., 2006) developed a process-focused grid-inspired assessment approach to improve collaborative design communication. More specifically, ten key factors have been highlighted and grouped into five categories: organisation, team, product, information and communication, to build up a communication grid for an assessment of design communication (Maier et al., 2008).

Although many DPM indicators and criteria have been established in the NPD context, little research has focused on improving collaborative design at a design stage. According to the study from MacBryde and Mendibil (2003), while the existing DPM frameworks enable companies to measure the design performance from both product and process viewpoints, at the grass roots level, they were struggling to find a way of managing their design team collaboration. Therefore, our research on measuring 
IJPPM

60,2

\section{6}

collaborative design performance during a design process contributes to the improvement of the design team collaboration.

\section{Research methodology}

According to the aforementioned two research questions, there are two phases in this study:

(1) investigation of collaborative design performance indicators; and

(2) exploration of detailed DPM criteria for measuring these indicators during a design process.

The following research methods: literature review, focus group and questionnaire, have been carefully selected for this study (Table I).

In phase one, the literature review and focus group have been conducted in a sequential process to investigate key indicators of collaborative design performance. Specifically, a literature review was applied to collect possible DPM indicators from previous studies. Afterwards, a focus group was implemented to identify the most crucial indicators for collaborative design based on results of the literature review. The literature review was chosen as a research method due to the fact that it can better support researchers to establish subject background, learn from other research, formulate research problems, synthesise the work of others, and compare with other research strategies (Ridley, 2008). Moreover, the focus group was selected because it is a quick means to obtain rich data from participants' opinions and deeper insights (Krueger, 2000). In addition, the participants in a focus group are able to build on one another's responses and generate new ideas (Morgan, 1997). Thus, it can provide more information to support the discussion and analysis of collaborative design performance measurement, and, in turn, identify the most important DPM indicators for it.

\begin{tabular}{|c|c|c|c|}
\hline $\begin{array}{l}\text { Research } \\
\text { process }\end{array}$ & Research questions & $\begin{array}{l}\text { Research } \\
\text { methods }\end{array}$ & Objectives \\
\hline Phase one & $\begin{array}{l}\text { What indicators can be used to } \\
\text { represent collaborative design } \\
\text { performance? }\end{array}$ & $\begin{array}{l}\text { Literature } \\
\text { review } \\
\text { Focus group }\end{array}$ & $\begin{array}{l}\text { To explore possible DPM } \\
\text { indicators } \\
\text { To discuss and identify the } \\
\text { important indicators for } \\
\text { collaborative design from the } \\
\text { possible DPM indicators }\end{array}$ \\
\hline Phase two & $\begin{array}{l}\text { What criteria can be used to } \\
\text { measure each of the identified } \\
\text { indicators during a design process? }\end{array}$ & $\begin{array}{l}\text { Literature } \\
\text { review } \\
\text { Focus group }\end{array}$ & $\begin{array}{l}\text { To explore possible criteria for } \\
\text { each collaborative design indicator } \\
\text { To discuss and classify suitable } \\
\text { criteria for each collaborative } \\
\text { design indicator from the potential } \\
\text { criteria } \\
\text { To investigate the most important } \\
\text { criteria for each collaborative } \\
\text { design indictor, and to find out how } \\
\text { many criteria should be involved in } \\
\text { an effective DPM matrix }\end{array}$ \\
\hline
\end{tabular}

Table I.

Research methodology 
In phase two, the literature review and focus group were conducted to explore and classify detailed criteria for each of the collaborative design indicators resulting from phase one. Subsequently, a questionnaire study was applied to explore what are the most important DPM criteria for each indicator and how many detailed criteria should be involved to establish an effective DPM matrix. The questionnaire has been selected as a research instrument because it offers a very flexible way of collecting large volumes of data from large participant samples (Stanton et al., 2005). Furthermore, it has been widely used for large-scale investigations and has the potential to collect cognitive and affective data quickly and easily (Easterby-Smith et al., 2002; Kinshuk, 1996). In addition, many researchers have indicated that the questionnaire is cheaper to administer than other methods, and data collection is less time consuming (Stone and Collin, 1984). Due to these advantages, the questionnaire is an appropriate method to explore participants' opinions about what are the most important DPM criteria for each DPM indicator, and the appropriate number of DPM criteria for an effective DPM matrix. The following sections will describe the research process and results in detail.

\section{Investigation of collaborative design performance indicators}

In phase one, we wanted to discover the collaborative design performance indicators. Two steps were designed in this phase:

(1) exploration of the possible collaborative design indicators; and

(2) identification of the most important indicators for collaborative design performance measurement.

\subsection{Exploration of relevant collaborative design indicators}

In order to discover what indicators can be used to represent collaborative design performance, a literature review has been conducted. According to the research aim, we reviewed literature in the new product development (NPD), design performance measurement (DPM), and design management (DM) research fields. E-journal databases, namely, Emerald and Science-Direct, are used as the major sources for the literature review.

After conducting a comprehensive review of 82 studies in the relevant research areas, 13 possible collaborative design indicators were identified from previous research as they were strongly highlighted as key factors for NPD, such as collaboration, cross-functional integration, customer-based indicators, design efficiency, management skill, innovation, and product-level indicators (Table II). For instance, some research has demonstrated that better management skills can produce positive influences on NPD outcomes, such as reducing NPD risks and improving team collaboration (Cooper and Kleinschmidt, 1995; Bobrow, 1991). Innovation should be regarded an important indicator because it determines whether the product design has distinctiveness when compared with other products, whether the product design can satisfy customers' requirements and whether the product design can create sustainable competitive advantages for the company (Calantone et al., 1995).

These 13 indicators have been highlighted as key elements for successful NPD, concerning the whole product development process: from product specification, marketing research, design, manufacturing, sales, and service. Because our research focuses on measuring collaborative design during the design stages, which is part of the whole product development process, it is necessary to identify the key indicators 
IJPPM
60,2

158

Table II.

Summary of relevant design success indicators

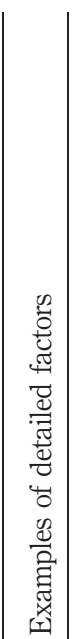

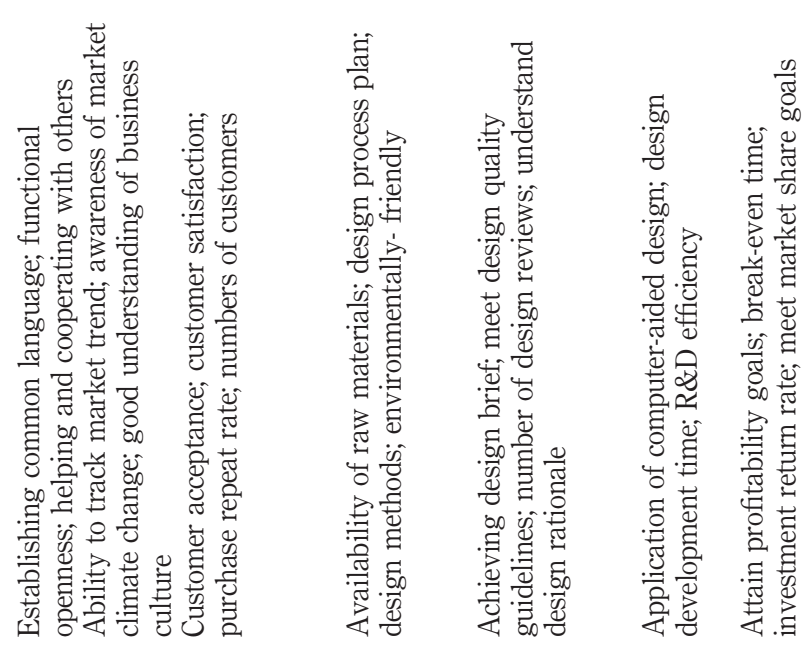

胥|

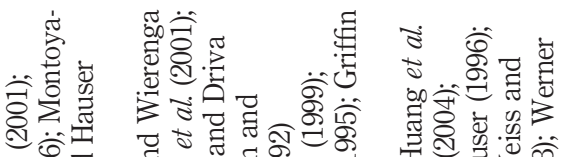

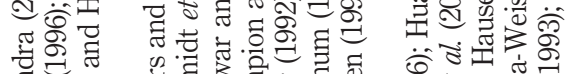

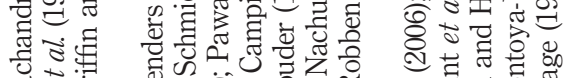

娄考

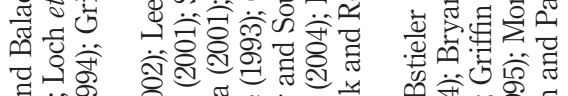

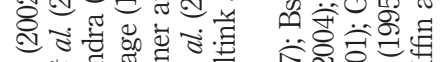

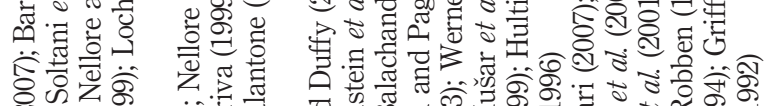

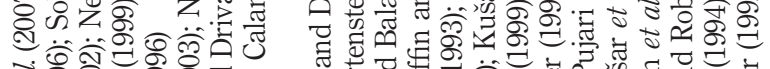

₹

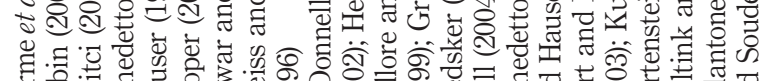

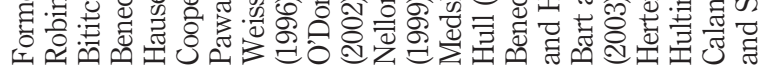

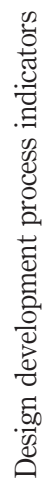

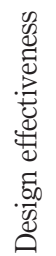




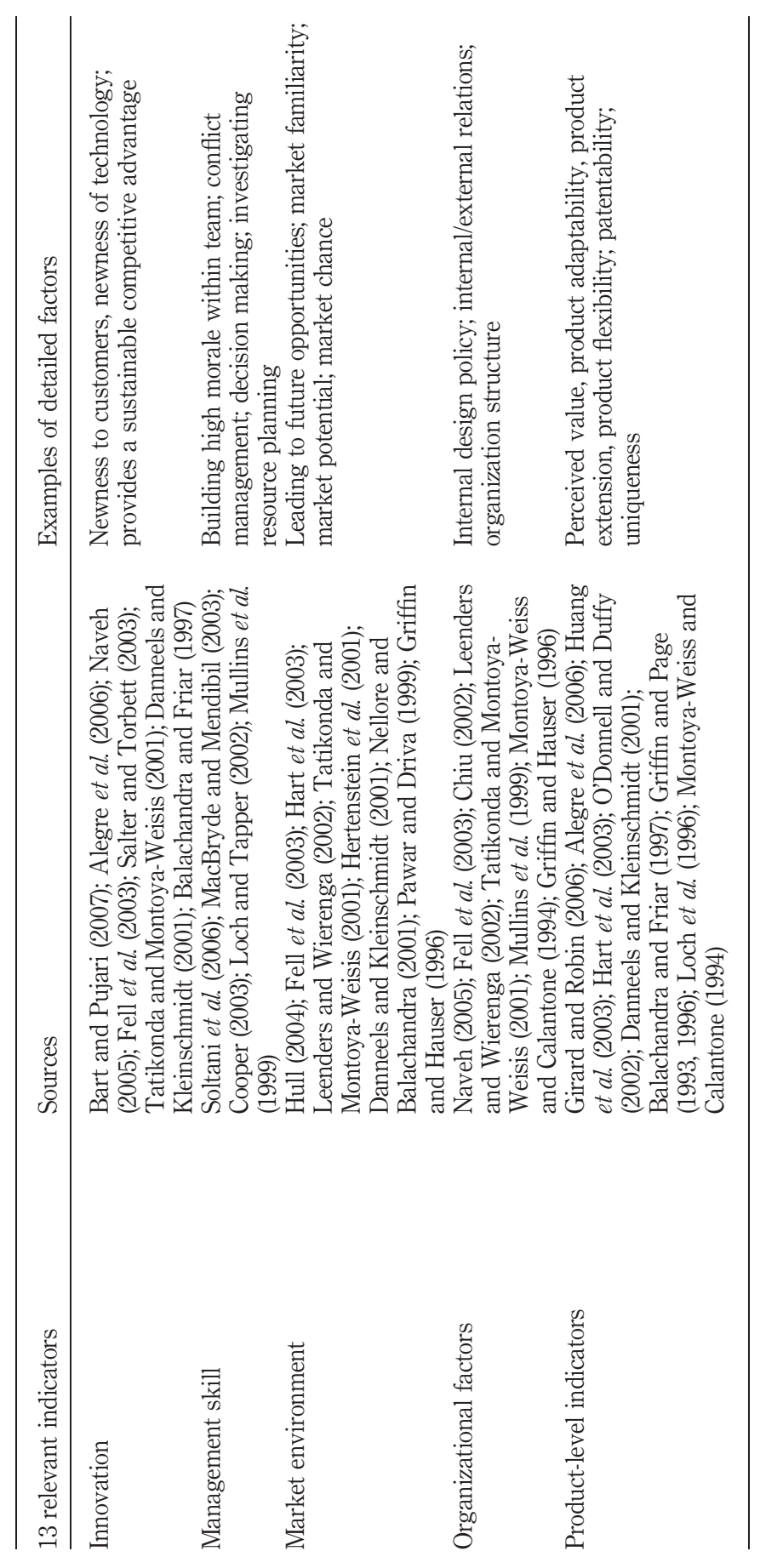

Design performance measurement

159

Table II. 
IJPPM

60,2 which are useful and measurable for collaborative design performance measurement based only on information available during the design process. Consequently, a focus group study has been delivered to discuss and identify the key indicators for collaborative design. These key indicators are a subset of the 13 key elements shown in Table II.

\subsection{Identification of the most important collaborative design performance indicators}

In order to explore whether the identified indicators are suitable for measuring collaborative design performance during a design process, a focus group was conducted in July 2007. Collaborative design industrialists and collaborative design researchers were selected as the target population, mainly because they have rich theoretical and practical experience of collaborative design, including activities, process, results, and challenges. Their various experiences in design research and practice enable them to be able to identify key indicators of collaborative design. Thirty focus group invitations were sent to the target population, whose contact information was collected from the Brunel Design Alumni, by e-mail, with an introductory cover letter. Ten design experts attended the focus group discussion. In order to clarify the participants' background and experiences, they were required to answer a list of questions at the beginning of the focus group study. Based on the response, 60 per cent of respondents were collaborative designers working in product design companies and four participants were design researchers working in universities and research organisations. More specifically, 70 per cent of the respondents focused on product design, 20 per cent $(N=10)$ on design management, and 10 per cent $(N=10)$ on engineering design.

During the three hours focus group study, five key questions were discussed: what is the core meaning of each of the 13 indicators, whether an indicator is closely related with collaborative design performance, whether an indicator has potential to be measured during a design process, whether an indicator has close relationship with other indicators (i.e. high correlated), and whether some other indicators, which are not included in the identified list, should be regarded as important collaborative design indicators.

During the focus group discussion, the 13 potential DPM indicators were deeply discussed and analysed based on participants' experiences from both research and industrial perspectives. As a result, some indicators were considered to be less important indicators for measuring collaborative design performance during a design process compared with others, such as financial and market environment indicators; and some indicators were combined into one because they are highly co-related, such as collaboration and cross-functional integration. In addition, three new indicators have been suggested and discussed: strategic design, design resources management, and customer relationship management. Finally, five indicators were considered as the most important measures for collaborative design performance measurement. They are:

(1) efficiency;

(2) effectiveness;

(3) collaboration;

(4) management skill; and

(5) innovation. 
These results are consistent with pervious research findings. For example, many researchers have highlighted that efficiency should be regarded as one of the most important performance measurement factors in collaborative design success (Naveh, 2005). In Bond et al. (2004) and Hull (2004), effectiveness has received more attention than other criteria in collaborative design research. With the five DPM indicators identified, there is a need to explore what detailed criteria can be used to measure the five collaborative design indicators, and, in turn, conduct DPM in practice.

\section{Investigation of collaborative design performance measurement criteria} In order to explore detailed criteria for collaborative design performance measurement, a literature review, focus group study and questionnaire were conducted in phase two. The study in phase two includes three steps:

(1) investigation of potential DPM criteria for each collaborative design indicator;

(2) exploration of suitable DPM criteria for each collaborative design indicator; and

(3) identification of the most important DPM criteria for each collaborative design indicator.

The following sections will describe these three steps in greater detail.

\subsection{Investigation of potential DPM criteria}

Based on the five DPM indicators, a second literature review was operated to discover detailed criteria for each of the five in the NPD, design management, performance measurement, and design performance measurement research areas. The five DPM indicators were utilized as key words to conduct searching in the related research areas. Subsequently, detailed potential DPM criteria, which have been indicated as key factors for the five DPM indicators, were collected from previous research. As a result, 261 detailed criteria were identified as potential DPM criteria for measuring collaborative design during a design process.

\subsection{Exploration of suitable DPM criteria}

In order to discover whether all of the 261 detailed potential DPM criteria are suitable for measuring the five collaborative design performance indicators during a design process, a further focus group study was conducted in January 2008. The focus group invitation process was similar to phase one. Thirty focus group invitations were sent to the target population, and, ultimately, 13 design experts attended the focus group discussion. Among the 13 participants, 61.54 per cent $(N=13)$ were collaborative designers and 38.46 per cent $(N=13)$ were collaborative design researchers. Of the respondents, 76.92 per cent $(N=13)$ focused on collaborative product design, 15.38 per cent $(N=13)$ on collaborative design management and 15.38 per cent $(N=10)$ on collaborative engineering design. During the focus group study, five questions were discussed in order to investigate suitable DPM criteria for the five indicators, in terms of what are core meanings of every detailed potential DPM criteria, whether a criterion can be used to measure the DPM indicators, whether a criterion is measurable during a design process, whether a criterion has close co-relation with others, and whether some other relevant criteria, which is not included in the classified lists, should be added. During the discussion, six new criteria, which are design trust, ability to build brand reputation, ability to encourage employees to believe in value of product, ability to sell 
IJPPM

60,2

162 their design, ability to communicate well by persuasion, and ability to communicate well confidence, were recruited and discussed. Consequently, they identified and classified suitable detailed DPM criteria for each of the five DPM indicators. As a result of the focus group study, 158 detailed DPM criteria were identified as suitable criteria for measuring collaborative design performance during a design process and classified into the five DPM measures based on their core meanings. More specifically, they are classified as follows: 33 into efficiency, 39 into effectiveness, 25 into collaboration, 26 into management skill, and 35 into innovation (Appendix 1 - Table AI).

According to those of Brown and Eisenhardt (1995) and Maskell (1989), the measures should be simple and easy to implement, and under the control of an organizational unit (Globerson, 1985). Therefore, 158 DPM criteria are too many to be operated as an efficient DPM matrix in a design process. Thus, in order to reduce the number of DPM criteria, there is a need to identify the most important ones based on their relative priorities. Meanwhile, the number of detailed DPM criteria that should be included in a DPM matrix needs to be determined so that the remainder can be ignored.

\subsection{Identification of the most important DPM criteria}

A questionnaire survey was designed with close-ended, open-ended, and ranking questions to gauge the participants' profile, to identify the most important DPM criteria from the 158 criteria, and to investigate how many criteria should be included in a DPM matrix.

With the intention of creating a valuable DPM matrix, design industrialists were selected as the target population for this study. More specifically, the target population comprised top design managers (including design managers, design project managers, etc.), middle design managers (including design directors, middle design managers, and heads of design teams), and designers (including product designer, graphic designers, engineering designer). These groups of people were selected mainly because they had rich practical experience of DPM implementation including activities, processes, results, problems, and challenges. Such abundant experience can provide valuable information and suggestions for this study.

The questionnaire survey was conducted based on a web-based questionnaire survey system (www.freeonlinesurvey.com) from April to September 2008. The survey system allows multi-types of questions to be set up in a questionnaire, such as open-ended questions, closed-ended questions, multi options questions, and ranking questions. Web-based questionnaires were sent to the target participants by e-mail, with an attached cover letter briefly explaining the purpose of the questionnaire survey. Participants could answer questionnaires online, with the data automatically saved in an online database. The biggest advantage of the web-based questionnaire survey system is that the questionnaire can be easily created and distributed. In addition, all the collected data can be exported as an Excel document, which can be used straightforwardly for statistical analysis. The disadvantage of the web-based questionnaire survey system is that it is difficult to reach some participants who do not use the internet.

The participants were selected from 127 product design companies based on the Design Business Association Design Directory, including design managers, project managers, and designers. 200 invitation e-mails were sent out, and 48 valid feedbacks were received. The questionnaire return rate was 24 per cent $(N=200)$. The 48 returned 
questionnaires were received from 18 designers, 17 design directors, and 13 design managers. Among the 48 respondents, the job responsibilities ranged from design strategy, design management, design research, industrial design, to engineering design. Specifically, 36 per cent $(N=48)$ of respondents focused on industrial design, 27 per cent $(N=48)$ on design management, 21 per cent $(N=48)$ on design strategy, 8 per cent $(N=48)$ on design research, and the other 8 per cent $(N=48)$ on engineering design.

In the questionnaire survey, after the personal information section, the participants were asked to select and rank five essential criteria for each of the five collaborative design indicators from the classified items. The rank value ranges from 1 to 5 , where 5 is the most important and 1 is the least important. The reason for choosing five criteria is based on the suggestion that it is normally advisable to restrict the number of items to a maximum of six for ranking questions (Stanton et al., 2005).

Based on the questionnaire results, two measures of frequency and average ranking were formulated for picking up the most important criteria for each indicator. The frequency was calculated by the ratio of the number of selections and the total number of participants. It was calculated by the formula $F=S / N$. Here, $F$ represents frequency for each DPM criteria, $S$ corresponds to the sum of selection times for each criterion, and $N$ is the total number of participants. The average ranking was analysed according to the total of ranking scores received for each criterion and the total number of participants. The calculation formula is $A=R / N=\sum_{i=1}^{S} r_{i} / N$. Here, $A$ represents average ranking for each criterion, $R$ corresponds to the sum of ranking scores received for each criterion from the participants, and $r_{i}$ is the individual ranking value.

We use these two measures as critical parameters because the former indicates how many of participants regard a criterion as an important one and the latter represents relative importance comparisons among them. Therefore, the frequency measure indicates whether a criterion is an important factor or not. Thus, we used this measure to identify the list of most important criteria. Subsequently, we used the average ranking to rank the items in the list. This means that if items had the same or similar frequency, the different average ranks can distinguish their positions in the list. This enabled the researchers to address how many detailed DPM criteria should be involved in a design matrix. According to the results, 68 per cent $(N=48)$ of the participants believed that 25 is an appropriate number of criteria for a DPM matrix. Tables III-VII present the top 20 criteria in each of the efficiency, effectiveness, collaboration, management skills, and innovation areas in descending order of frequency. The top five criteria are selected from each of the five tables to generate the 25 criteria for incorporation into a DPM matrix for collaborative design.

5.3.1 Key criteria for collaborative design efficiency. As shown in Table III, decision-making efficiency, problem solving, personal motivation, ability to work under pressure, and $\mathrm{R} \& \mathrm{D}$ process well planned were selected as the most important DPM criteria for design efficiency. Among these five items, 72.74 per cent of the 48 participants believed that the decision-making efficiency was the most essential criterion for measuring design efficiency. A possible explanation for this finding is that, due to the competitive pressures, limited resources and accelerating costs, it is difficult to make the right decision efficiently (Cooper and Kleinschmidt, 1986). Therefore, whether or not design team members have the ability to make a decision 


\section{IJPPM \\ 60,2}

\section{4}

Table III.

Identified efficiency PM criteria

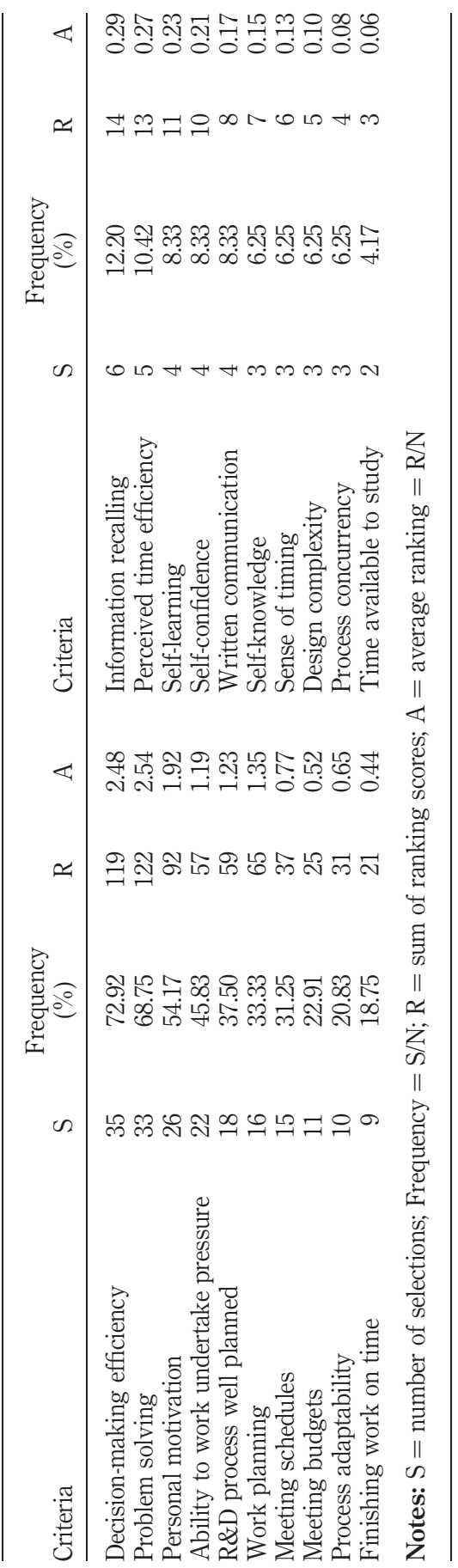




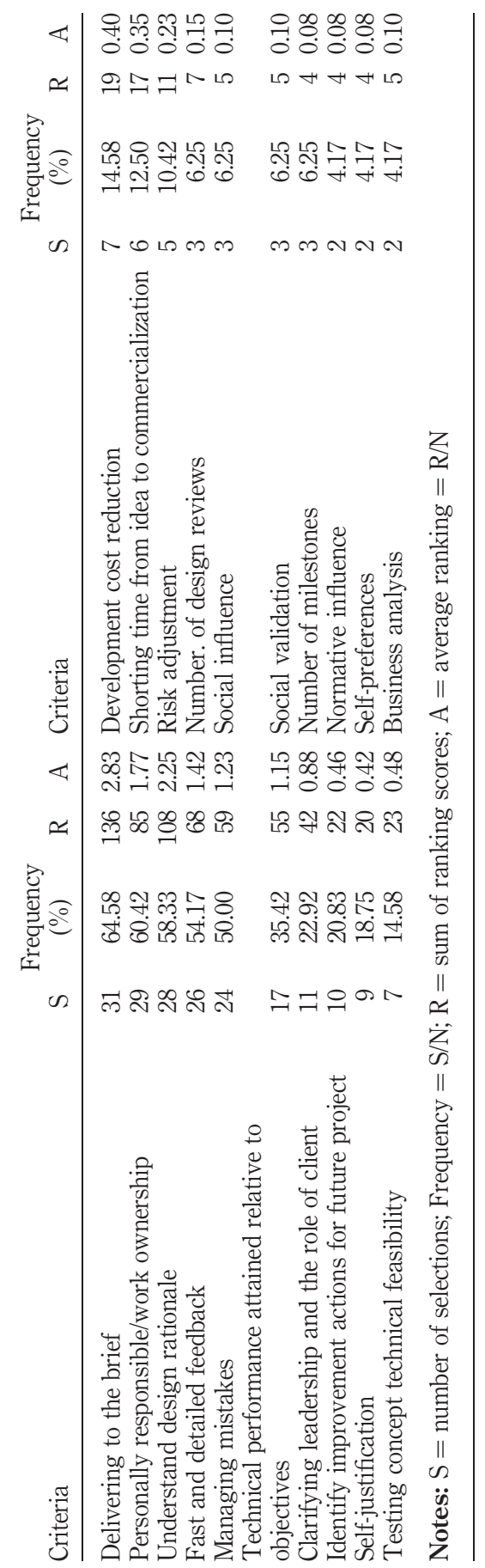

\section{Design performance measurement}

165

Table IV. Identified design effectiveness PM criteria 


\section{IJPPM}

60,2

\section{6}

Table V.

Identified collaboration

PM criteria

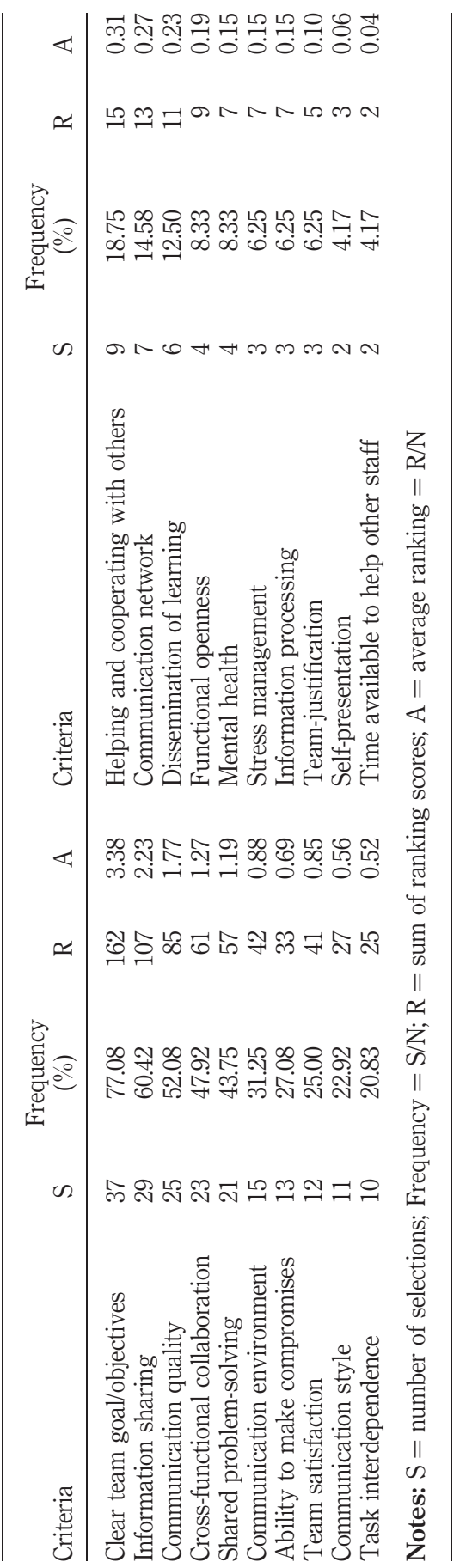




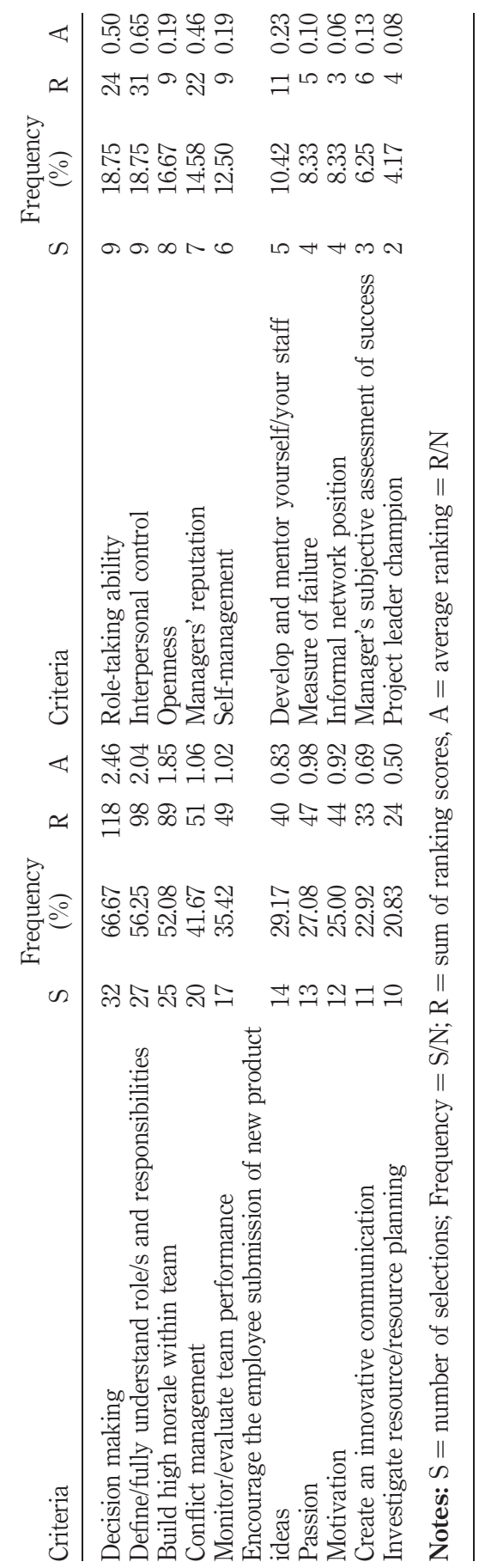

\section{Design performance measurement}

167
Table VI. Identified design management skill PM criteria 


\section{IJPPM \\ 60,2}

\section{8}

Table VII.

Identified innovation PM criteria

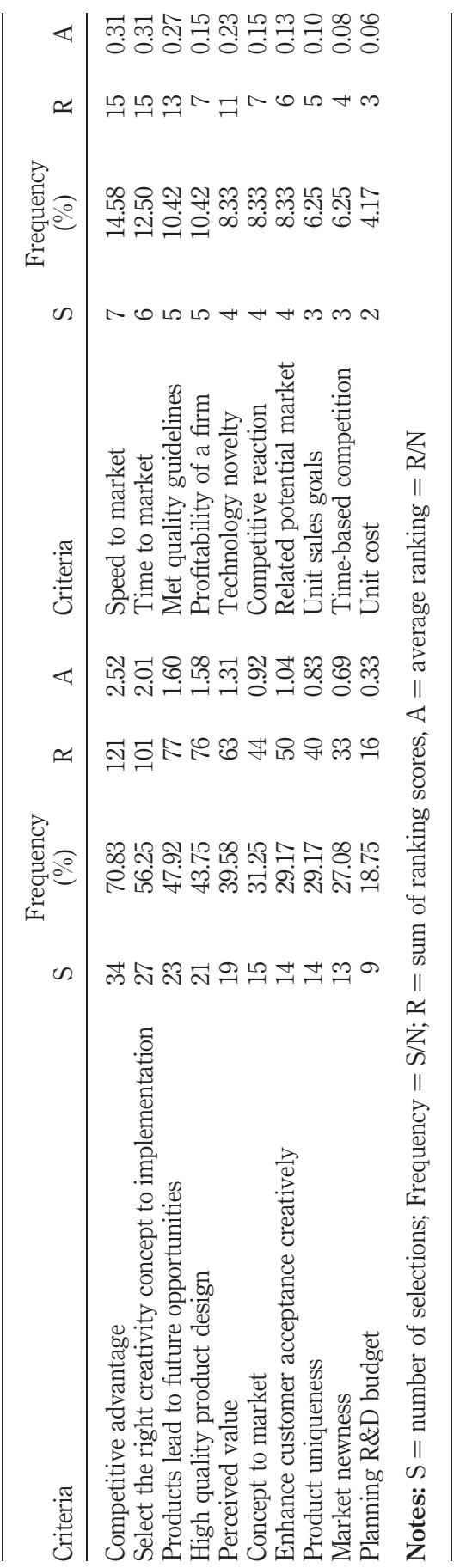


efficiently becomes a vital element. This finding is also consistent with those of Busseri and Palmer (2000) and Schmidt et al. (2001), which indicated that efficient decision-making was crucial for final project outcomes as it has very positive influences on maintaining project control and the NPD team collaboration. On the other hand, from the average ranking perspective, problem solving was chosen as the most important criterion to measure design efficiency. This result echoes those of Smither (1998) and Loch and Tapper (2002), which indicated that efficient problem solving skills can increase learning and improvement ability of project staff and their behaviour. In addition, as the design process always involves multi-background staff and new buyer-supplier relationships (Wognum et al., 2002), the complex collaboration might produce more problems when compared with other projects. Therefore, problem solving skill was highlighted as one of the most important DPM criteria.

5.3.2 Key criteria for collaborative design effectiveness. The questionnaire results presented in Table IV shows that delivering to the brief, personally responsible/work ownership, understand design rationale, fast and detailed feedback, and managing mistakes have been regarded as the most important design effectiveness PM criteria. Among these five, the ability of delivering brief was selected by 63.66 per cent $(N=48)$ of the participants as the most critical element of design effectiveness performance measurement from both frequency and average ranking aspects. This result echoes those of the Hart et al. (2003), Fell et al. (2003), and Naveh (2005), which indicated delivering to brief is an important element for NPD effectiveness. It is probably because the global competitive environment has impelled design companies to deliver high-quality design during the design process in order to satisfy customers' requirements, launch a new product into the market on time, and, in turn survive, and win the market.

5.3.3 Key criteria for collaborative design collaboration. Table V highlights that the five most important criteria which influence design collaboration PM are clear team goal/objectives, information sharing, communication quality, cross-functional collaboration, and shared problem-solving. Among these top five criteria, 81.84 per cent $(N=48)$ of the participants believed clear team goal/objectives was the most important criteria by which to measure design collaboration performance. This result is consistent with that of Belbin (1993), which indicated that fully understanding the goal/objectives of the project team can reduce misunderstanding and increase team collaboration. In addition, 63.63 per cent $(N=48)$ of the participants considered that information sharing was the most important factor for design collaboration. This is probably because team individuals are limited in their ability to search for enough information, to recall information from memory, and to make selections from multiple criteria (Staw, 1981). Therefore, members can support each other by sharing information with colleagues with different knowledge and skills (Steiner, 1972; McGrath and Romeri, 1994). Such information sharing can increase teams' collaboration performance.

5.3.4 Key criteria for collaborative design management. Results shown in Table VI indicate that design making, define/fully understand roles and responsibilities, build high morale within team, conflict management, and monitor/evaluate team performance are the five most important criteria for design management skill performance measurement. 68.23 per cent $(N=48)$ of the participants regarded decision making as the most important criterion for measuring design management skill. This 
IJPPM

60,2

170 is probably because the decision making in a design process always requires a degree of management ability to deal with a large amount of information (Twigg, 1998), a dynamic and fast changing market, and multiple alternatives and criteria in an uncertain environment (Feltham and Xie, 1994). Therefore, a good decision maker can drive a design project team to achieve the ultimate project goal more efficiently and effectively.

5.3.5 Key criteria for collaborative design innovation. Table VII presents the results of the importance of design innovation performance criteria ranking. Of the participants, 72.77 per cent $(N=48)$ considered competitive advantage as the most relevant and important criterion for design innovation performance measurement. In other words, high design innovation performance depends on whether the product design can provide competitive advantages. This finding is consistent with those of Griffin and Page $(1993,1996)$ and Fell et al. (2003), which indicated that the ability of providing a sustainable competitive advantage was a key factor of NPD success and crucial element to win the global market. 63.68 per cent $(N=48)$ of the participants believed that the capacity to select the right creativity concept was an important factor in design innovation performance. This may be due to the fact that the capacity to select the right creativity concept can support the future market trend and the future customer requirements. The right selection of the creativity concept requires a good understanding of the new product and the market. This good understanding can reduce risks of the selected creativity concept, to win the future market (Gaynor, 1990). Therefore, the capacity to select the right creativity concept is an essential factor for design innovation performance measurement.

According to the questionnaire results, a design performance matrix was established, based on the top 25 criteria and the five DPM indicators (Table VIII).

\subsection{Discussion}

5.4.1 DPM matrix implementation. The DPM matrix can be implemented to support design managers and designers in measuring design performance based only on information typically available during a design process, and, in turn, improve collaborative design. More specifically, due to the fact that collaborative design projects always involve a team of participants with diverse knowledge and experience, it is more difficult for them to work together effectively (Ali et al., 2008; Girard and Robin, 2006). The proposed DPM matrix can be applied to support collaborative design project team members in better understanding each other by providing multiple team collaboration feedback. Based on the DPM matrix, the design project team members' daily collaborative design performance can be measured in terms of the efficiency, effectiveness, collaboration, management skill, and innovation aspects by design managers and their design team colleagues. Subsequently, DPM results can be analysed to provide team feedback and information about the strengths and weaknesses of the design team members' collaborative design performance. The information can support design managers in better supervising and improving the project development process, providing an appropriate training plan for each single team member, and making decisions more efficiently and effectively. In addition, because a collaborative design process is extremely dynamic (Shen et al., 2008; Chua et al., 2003), the DPM results can help designers better recognize the current situation of their collaborative design performance for a certain stage during a design process. In 


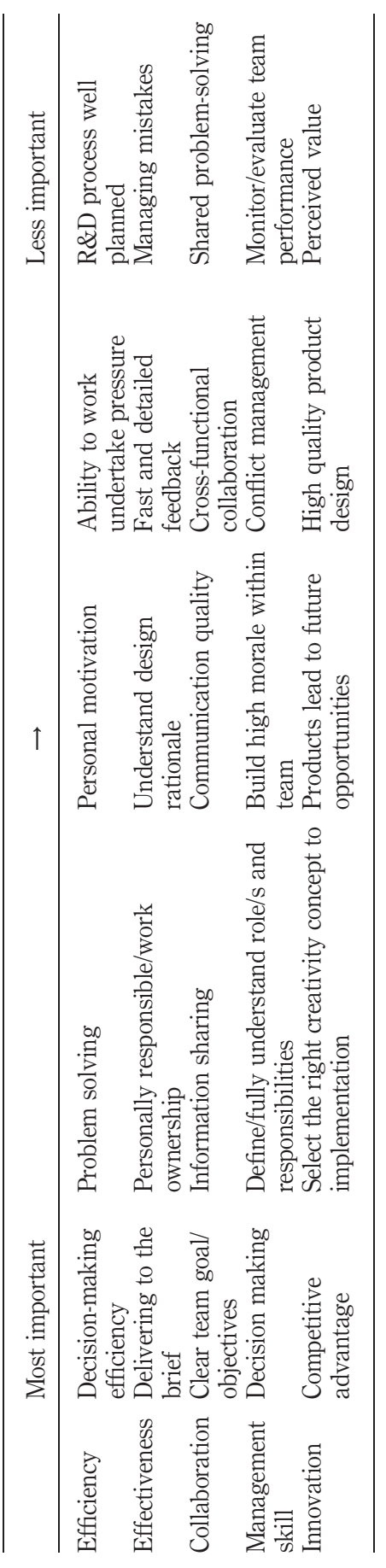

Design performance measurement

171

Table VIII.

DPM matrix 
IJPPM

60,2

172 turn, they can improve themselves according to the indicated weaknesses on the specific design stage.

For successful operation of the DPM matrix, both factual and experience-based information within the collaborative design development process are required. The former means accurate information about collaborative design processes, such as time, cost, number of design outcomes and statistical data. The latter represents design development information based on a design team member's experience during the design process, such as design activities, communication quality, and team interaction. During a collaborative design process, available factual information is varied along a development process due to the fact that design effect levels are not directly observable, while the consequences of design actions are not directly observable, and there is high level of uncertainty in the whole design process (Shen et al., 2008; Chua et al., 2003; Feltham and Xie, 1994; Craig and Hart, 1993). For example, many researchers have suggested that a product's competitive advantages can be measured based on market share, investment return rate, and customers' feedback. However, as this data is not normally available during a design process, it is difficult to assess the product's competitive advantage before the product launch. Therefore, there is a need to integrate factual and experience-based information together in order to maintain DPM implementations to provide substantial and constant information concerning collaborative design during a design process. Some researchers have highlighted that competitive advantages can be measured during a design process according to experience information, such as an understanding of competitors, good working knowledge and comparing numbers on brochures (Moultrie, 2004). Therefore, the proposed matrix provides strategies to conduct a comprehensive and constant DPM during a design process by integrating both factual and experience-related collaborative design performance information.

During a collaborative design project development process, factual information for DPM can be collected from the collaborative design project operation data records during the design process, such as date of starting and ending point of each design task, e-mail exchange, meeting minutes, project brief and plan, budget plan, results of each design task (e.g. concept design draft, prototype modelling, and detailed design graphics), and DPM results. This data can be utilized as factual evidence to measure a team member's collaborative design performance, such as whether a member meets a design brief on time and within a budget plan, whether the member provides fast and detailed feedback via e-mails and meetings, whether the member has ability to work under pressure, and whether the member supplies rich information sharing. On the other hand, experience-related information for DPM matrix operation can be gathered through a DPM questionnaire, which requires the collaborative design team members to judge their colleagues' performances based on daily team collaboration, addressing efficiency, effectiveness, collaboration, management skill, and innovation against the 25 DPM criteria. In addition, team members' judgements and feedbacks should depend on the current design environment and project context. With the intention to decrease negative influences of staff's subjective attitudes to the DPM questionnaire results, a multi-feedback performance measurement approach can be applied to minimize the chance of any one person's bias unduly influencing a DPM decision (Smither, 1998). Therefore, in order to operate DPM in a comprehensive and balanced way with all the design team members, a team member's collaborative design performance should not 
only be evaluated by his/her manager, but also by the same level colleagues, lower level design staff and him/herself through the DPM questionnaire. By doing so, every team member's performance can be collectively evaluated by the design project team members.

During a collaborative design process, the DPM matrix could be implemented to measure design performance by following the process below:

(1) Identify design project team members as the top design manager, middle 173 managers, and individual designers based on their job roles in order to clarify "manager", "the same level colleagues" and "the lower level design staff".

(2) Based on the DPM matrix, the project team members' daily collaborative design performance could be measured from efficiency, effectiveness, collaboration, management skill, and innovation aspects by their "manager", "the same level colleagues", "the lower level design staff" and themselves via the DPM questionnaire. Subsequently, DPM data should be collected by themselves, their design manager, their same level colleagues, and their sub level designers.

(3) Next, the DPM data should be calculated to produce DPM scores for each design team member.

(4) Subsequently, DPM results should be analysed to provide information about the strengths and weaknesses of the design team members.

(5) The information should be able to support design managers to better supervise and improve the design project development process, provide an appropriate training plan for each single team member, and make decisions more efficiently and effectively. In addition, the information should also be able to help the other design staff to better understand the current situation of their design performance. Consequently, they can improve themselves according to the indicated weaknesses.

(6) By comparing previous and current DPM results it will be possible to see whether the design team members' response actions have made positive improvements to the design development.

(7) The number of DPM operation times during a design process can be determined by the project features, such as size, number of team members, and time plan.

Because availabilities of collaborative design performance information are varied during a design process, the collaborative design performance will be measured based on a variety of factual and experience information at different design stages, according to the DPM criteria. In addition, what information should be utilized to conduct DPM for different design stages is also varied with different design projects based on their strategies. Thus, it is difficult to develop a universal DPM information map to support DPM implementation. Therefore, the proposed DPM matrix should be used as guidelines to lead the DPM operation in different collaborative design projects based on available factual and experience information only. The detailed collaborative design performance information for each of the criteria at different design stages should be identified by design managers according to the specific features of the project. For instance, the specific DPM criterion "delivering to the brief" may be demonstrated by information concerning "achieving all detailed objectives in a design task with high 
IJPPM

60,2

174 quality" and "presentation of core brief value in design outcomes" (Appendix 2 Table AII).

5.4.2 Limitation of the present study. The present study was focused on exploring and developing a DPM matrix for measuring collaborative design performance during a design process. Therefore, some key DPM criteria, which are not measurable during a design development process, were not included in this study, such as investment return rate, market share, and customer satisfaction. However, the proposed DPM matrix has potential to be extended so as to examine collaborative design performance by following an entire product life process in future research. In addition, the proposed multi-feedback approach for DPM matrix implementation needs to be validated by industrial case studies.

\section{Conclusions}

Performance measurement has been increasingly developed and operated to improve project and business performance, especially for some complex and large-scale projects (Vaneman and Triantis, 2007). Because of the great complexity and uncertain features of the product collaborative design process (Twigg, 1998), there is a necessity for implementing performance measurement to control the project development, minimize collaboration conflicts, and reduce management risk during the design process, and, in turn, improve the final performance of the project.

The major contribution of this study is the investigation and development of a DPM matrix to measure collaborative design performance during a design process. Specifically, 25 DPM criteria, which address five DPM indicators: efficiency, effectiveness, collaboration, management skill, and innovation, have been highlighted as the most critical factors for collaborative design performance measurement. The results indicate that decision-making efficiency is the most important DPM criteria for collaborative design efficiency; delivering to the brief for effectiveness; clear team goal/objectives for collaboration; decision-making ability for management skill; and competitive advantage for innovation. These results can be used to conduct a DPM tool based only on information available at design stages in order to measure collaborative design performance during a design process. Owing to the limitations of the work presented in this paper, further research is focused on the extended DPM matrix development and the implementation of the DPM matrix.

\section{References}

Alegre, J., Lapiedra, R. and Chiva, R. (2006), "A measurement scale for product innovation performance", European Journal of Innovation Management, Vol. 9 No. 4, pp. 333-46.

Ali, A.S., Rahmat, I. and Hassan, H. (2008), "Involvement of key design participants in refurbishment design process", Facilities, Vol. 26 Nos 9/10, pp. 389-400.

Balachandra, R. and Friar, J.H. (1997), "Factors for success in R\&D projects and new product innovation: a contextual framework", IEEE Transactions on Engineering Management, Vol. 44 No. 3, pp. 276-87.

Bart, C. and Pujari, A. (2007), "The performance impact of content and process in product innovation charters", Journal of Product Innovation Management, Vol. 24 No. 1, pp. 3-19.

Belbin, R.M. (1993), Team Roles at Work, Butterworth- Heinemann, Oxford.

Benedetto, C. (1999), "Identifying the key success factors in new product launch", Journal of Product Innovation Management, Vol. 16, pp. 530-44. 
Bititci, U. (2002), "Integrated performance measurement system: an audit approach. Parts 1 and 2", Control, February/March.

Bobrow, E.E. (1991), "Successful new products are product of process", Marketing News, 15 April, p. 27.

Bond, E.U., Walker, B.A., Hutt, M.D. and Reingen, P.H. (2004), "Reputational effectiveness in cross-functional working relationships", Journal of Product Innovation Management, Vol. 21, pp. 44-60.

Brown, S.L. and Eisenhardt, L.M. (1995), "Product development: past research, present findings, and future directions", Academy of Management Review, Vol. 20 No. 2, pp. 343-78.

Bruce, M. and Bessant, J. (2002), Design in Business: Strategic Innovation through Design, Financial Times Management, London.

Bryant, L., Jones, D.A. and Widener, S.K. (2004), "Managing value creation within the firm: an examination of multiple performance measures", Journal of Management Accounting Research, Vol. 16, pp. 107-31.

Bstieler, L. (2006), "Trust formation in collaborative new product development", Product Innovation Management, Vol. 23, pp. 56-72.

Busseri, M.A. and Palmer, J.M. (2000), "Improving teamwork: the effect of self-assessment on construction design teams”, Design Studies, Vol. 21, pp. 223-38.

Calantone, R.J., DiBenedetto, C.A. and Haggblom, T. (1995), "Principles of new product management: exploring the beliefs of product practitioners", Journal of Product Innovation Management, Vol. 12, pp. 235-46.

Campion, M.A. and Medsker, G.J. (1993), "Relations between work group characteristics and effectiveness: implications for designing effective work groups", Journal of Personal Psychology, Vol. 46 No. 4, pp. 823-43.

Chen, C., Ling, S.F. and Chen, W. (2002), "Project scheduling for collaborative product development using DSM", International Journal of Project Management, Vol. 21, pp. 291-9.

Chiesa, V., Frattini, F., Lazzarotti, V. and Manzini, R. (2009), "Performance measurement of research and development activities", European Journal of Innovation Management, Vol. 12 No. 1, pp. 25-61.

Chiu, M.L. (2002), “An organizational view of design communication in design collaboration”, Design Studies, Vol. 23, pp. 187-210.

Chu, C., Cheng, C. and Wu, C. (2006), "Applications of the web-based collaborative visualization in distributed product development”, Computers in Industry, Vol. 57, pp. 272-82.

Chua, D.K.H., Tyagi, A., Ling, S. and Bok, S.H. (2003), "Process parameter-interface model for design management", Journal of Construction Engineering and Management, Vol. 129 No. 6, pp. 653-63.

Cooper, L.P. (2003), "A research agenda to reduce risk in new product development through knowledge management: a practitioner perspective", Journal of Engineering and Technology Management, Vol. 20, pp. 117-40.

Cooper, R.G. and Kleinschmidt, E.J. (1986), “An investigation into the new product process: steps, deficiencies, and impact”, Journal of Product Innovation Management, Vol. 3, pp. 71-85.

Cooper, R.G. and Kleinschmidt, E.J. (1995), "Benchmarking the firm's critical success factors in new product development", Journal of Product Innovation Management, Vol. 12, pp. 374-91.

Craig, A. and Hart, S. (1993), "Dimensions of success in new product development", Perspectives on Marketing Management, Vol. 3, Chapter 10, pp. 207-43. 
IJPPM

60,2
Danneels, E. and Kleinschmidt, E.J. (2001), "Product innovativeness from the firm's perspective: its dimensions and their relation with project selection and performance", Journal of Product Innovation Management, Vol. 18, pp. 357-73.

Easterby-Smith, M.P.V., Thorpe, R. and Lowe, A. (2002), Management Research: An Introduction, 2nd ed, Sage, London.

Fell, D.R., Hansen, E.N. and Becker, B.W. (2003), "Measuring innovativeness for the adoption of industrial products", Journal of Industrial Marketing Management, Vol. 32, pp. 347-53.

Feltham, G.A. and Xie, J. (1994), "Performance measure congruity and diversity in multi-task principal-agent relations", The Accounting Review, Vol. 69 No. 3, pp. 429-53.

Folan, P. and Browne, J. (2005), "A review of performance measurement: towards performance management”, Computers in Industry, Vol. 56, pp. 663-80.

Forme, F.G.L., Genoulaz, V.B. and Campagne, J. (2007), "A framework to analyse collaborative performance”, Computers in Industry, Vol. 58, pp. 687-97.

Gaynor, G.H. (1990), "Selecting projects”, Research-technology Management, Vol. 33 No. 4, July-August, pp. 43-5.

Girard, P. and Robin, V. (2006), "Analysis of collaboration for project design management", Computers in Industry, Vol. 57, pp. 817-26.

Globerson, S. (1985), "Issues in developing a performance criteria system for an organisation", International Journal of Production Research, Vol. 23, pp. 639-46.

Griffin, A. and Hauser, J.R. (1996), "Integrating R\&D and marketing: a review and synthesis of the literature", Journal of Product Innovation Management, pp. 191-216.

Griffin, A. and Page, L. (1993), "An interim report on measuring product development success and failure”, Journal of Product Innovation Management, Vol. 10, pp. 291-308.

Griffin, A. and Page, L. (1996), "PDMA Success measurement project: recommended measures for product development success and failure", Journal of Product Innovation Management, Vol. 13, pp. 478-96.

Hart, S., Hultink, E.J., Tzokas, N. and Commandeur, H.R. (2003), “Industrial companies' evaluation criteria in new product development gates", Journal of Product Innovation Management, Vol. 20, pp. 22-36.

Hertenstein, J., Platt, M.B. and Brown, D. (2001), "Valuing design: enhancing corporate performance through design effectiveness”, Design Management Journal, Vol. 12 No. 3, pp. 10-19.

Hertenstein, J., Platt, M.B. and Veryzer, R.W. (2005), "The impact of industrial design effectiveness on corporate financial performance", Product Innovation Management, Vol. 22, pp. 3-21.

Huang, X., Soutar, G.N. and Brown, A. (2003), "Measuring new product success: an empirical investigation of Australian SMEs", Journal of Industrial Marketing Management, Vol. 33, pp. $117-23$.

Hull, F.M. (2004), "A composite model of product development effectiveness: application to services”, IEEE Transactions on Engineering Management, Vol. 51, pp. 162-72.

Hultink, E.J. and Robben, H.S.J. (1995), "Measuring new product success: the difference that time perspective makes", Journal of Product Innovation Management, Vol. 12, pp. 392-405.

Kennerley, M. and Neely, A. (2003), "Measuring performance in a changing business environment", International Journal of Operations \& Production Management, Vol. 23, pp. 213-29. 
Kinshuk (1996), "Computer-aided learning for entry-level accountancy students", $\mathrm{PhD}$ thesis, DeMontfort University, Leicester.

Krueger, R.A. (2000), Focus Groups: A Practical Guide for Applied Research, 3rd ed., Sage, Newbury Park, CA.

Kušar, J., Dunovnik, J., Grum, J. and Starbek, M. (2004), "How to reduce new product development time", Journal of Robotics and Computer-integrated Manufacturing, Vol. 20, pp. 1-15.

Lahti, H., Seitamaa-Hakkarained, P. and Hakkarainen, K. (2004), "Collaboration patterns in computer supported collaborative designing”, Design Studies, Vol. 25, pp. 351-71.

Leenders, M. and Wierenga, B. (2002), "The effectiveness of different mechanisms for integrating marketing and R\&D”, Journal of Product Innovation Management, Vol. 19, pp. 305-17.

Loch, C., Stein, L. and Terwiesch, C. (1996), "Measuring development performance in the electronics industry", Journal of Product Innovation Management, Vol. 13, pp. 3-20.

Loch, C.H. and Tapper, U.A.S. (2002), "Implementing a strategy-driven performance measurement system for an applied research group", Journal of Product Innovation Management, Vol. 19, pp. 185-98.

McGrath, M.E. and Romeri, M.N. (1994), "From experience the R\&D effectiveness index: a metric for product development performance", Journal of Product Innovation Management, Vol. 11, pp. 213-20.

MacBryde, J. and Mendibil, K. (2003), "Designing performance measurement systems for teams: theory and practice”, Management Decision, Vol. 41 No. 8, pp. 722-33.

Maier, A.M., Echert, C.M. and Clarkson, P.J. (2006), "Identifying requirements for communication support: a maturity grid-inspired approach”, Expert Systems with Applications, Vol. 31 No. 4, pp. 663-72.

Maier, A.M., Kreimeyer, M., Hepperle, C., Eckert, C.M., Lindemann, U. and Clarkson, P.J. (2008), "Exploration of correlations between factors influencing communication in complex product development", Concurrent Engineering: Research and Applications, Vol. 16 No. 1, pp. 37-59.

Maskell, B. (1989), "Performance measures of world class manufacturing", Management Accounting, May, pp. 32-3.

Montoya-Weiss, M.M. and Calantone, R. (1994), "Determinants of new product performance: a review and meta-analysis", Journal of Product Innovation Management, Vol. 11, pp. 397-417.

Morgan, D.L. (1997), Focus Groups as Qualitative Research, 2nd ed., Qualitative Research Methods Series 16, Sage, Newbury Park, CA.

Moultrie, J. (2004), "Development of a design audit tool to assess product design capability", $\mathrm{PhD}$ thesis, University of Cambridge, Cambridge.

Moultrie, J., Clarkson, P.J. and Probert, D.R. (2006a), "A tool to evaluate design performance in SMEs", International Journal of Productivity and Performance Measurement, Vol. 55 No. 3, p. 4.

Moultrie, J., Clarkson, P.J. and Probert, D.R (2006b), "Development of product audit tool", Proceedings of the Institution of Mechanical Engineers (Part B), Engineering Manufacture, Vol. 220 No. 7, pp. 1157-74.

Mullins, J.W., Forlani, D. and Walker, O.C. Jr (1999), "Effects of organisational and decision-maker factors on new product risk taking", Journal of Product Innovation Management, Vol. 16, pp. 282-94. 
IJPPM

60,2

178
Nachum, L. (1999), "Measurement of productivity of professional services an illustration on Swedish management consulting firms", International Journal of Operations \& Production Management, Vol. 19 No. 9, pp. 922-49.

Naveh, E. (2005), “The effect of intergraded product development on efficiency and innovation”, International Journal of Production Research, Vol. 43 No. 13, pp. 2789-801.

Neely, A., Gregory, M. and Platts, K. (2005), "Performance measurement system design: a literature review and research agenda", International Journal of Operations \& Production Management, Vol. 25, pp. 1228-63.

Neely, A., Richards, H., Mills, J., Platts, K. and Bourne, M. (1997), "Designing performance measures: a structured approach", International Journal of Operations \& Production Management, Vol. 17 No. 11, pp. 1131-52.

Nellore, R. and Balachandra, R. (2001), "Factors influencing success in integrated product development projects", IEEE Transactions on Engineering Management, Vol. 48 No. 2, pp. 164-74.

O’Donnell, F.J. and Duffy, A.H.B. (2002), "Modelling design development performance", International Journal of Operations \& Production Management, Vol. 22 No. 11, pp. 1198-221.

Pawar, K.S. and Driva, H. (1999), "Performance measurement for product design and development in a manufacturing environment", International Journal of Production Economics, Vol. 60-61, pp. 61-8.

Qin, S.F., Harrison, R., West, A.A., Jordanov, I.N. and Wright, D.K. (2003), "A framework of web-based conceptual design", Computers in Industry, Vol. 50, pp. 153-64.

Ridley, D. (2008), The Literature Review: a Step-by-step Guide for Students, Sage, London.

Salomo, S., Weise, J. and Gemünden, H.G. (2007), "NPD planning activities and innovation performance: the mediating role of process management and the moderating effect of product innovativeness", Product Innovation Management, Vol. 24, pp. 285-302.

Salter, A. and Torbett, R. (2003), "Innovation and performance in engineering design", Journal of Construction Management and Economics, Vol. 21, pp. 573-80.

Schmidt, J.B., Montoya-Weiss, M.M. and Massey, A.P. (2001), "New product development decision-making effectiveness: comparing individuals, face-to-face teams, and virtual teams", Journal of Decision Sciences, Vol. 32 No. 4, pp. 575-600.

Sharif, S.A. and Kayis, B. (2007), "DSM as a knowledge capture tool in CODE environment", Journal of Intelligent Manufacturing, Vol. 18, pp. 497-504.

Shen, W., Hao, Q. and Li, W. (2008), "Computer supported collaborative design: retrospective and perspective", Computers in Industry, Vol. 59, pp. 855-62.

Smither, J.W. (1998), Performance Appraisal: State of the Art in Practice, Jossey-Bass, London.

Soltani, E., Meer, R.V.D., Williams, T.M. and Lai, P. (2006), "The compatibility of performance appraisal system with TQM principles - evidence from current practice", International Journal of Operations \& Production Management, Vol. 26 No. 1, pp. 92-112.

Stanton, N.A., Salmon, P.M., Walker, G.H., Baber, C. and Jenkins, D.P. (2005), Human Factors Methods: A Practical Guide for Engineering and Design, Ashgate, Aldershot.

Staw, B.M. (1981), "The escalation of commitment to a course of action", Academy of Management Review, Vol. 6, pp. 577-87.

Steiner, I.D. (1972), Group Process and Productivity, Academic Press, New York, NY.

Stone, S. and Collin, H. (1984), CRUS Guide, Designing a User Study: General Research Design, Centre for Research on User Studies, University of Sheffield, Sheffield. 
Tatikonda, M.V. and Montoya-Weisis, M.M. (2001), "Integrating operations and marketing perspectives of product innovation: the influence of organizational process factors and capabilities on development performance", Journal of Management Science, Vol. 47 No. 1, pp. 151-72.

\section{Design performance measurement}

Tay, F.E.H. and Roy, A. (2003), "CyberCAD: a collaborative approach in 3D-CAD technology in a multimedia-supported environment", Computers in Industry, Vol. 52, pp. 127-45.

TSB (2009), "Design and decision tools for low impact building report", Technology Strategy Board, available at: www.innovateuk.org

179

Twigg, D. (1998), "Managing product development within a design chain", International Journal of Operations \& Production Management, Vol. 18, pp. 508-24.

Vaneman, W.K. and Triantis, K. (2007), "Evaluating the productive efficiency of dynamical systems", IEEE Transactions on Engineering Management, Vol. 54, pp. 600-12.

Werner, B.M. and Souder, W.E. (1992), "Measuring R\&D performance - state of the art", Research Technology Management, Vol. 40 No. 2, pp. 34-42.

Wognum, P.M., Fisscher, O.A.M. and Weenink, S.A.J. (2002), "Balanced relationships: management of client-supplier relationships in product development", Technovation, Vol. 22, pp. 341-51.

Zha, X.F. and Du, H. (2006), "Knowledge-intensive collaborative design modelling and support Part I: review, distributed models and framework", Computers in Industry, Vol. 57, pp. 39-55.

Zhang, S., Shen, W. and Ghenniwa, H. (2004), "A review of internet-based product information sharing and visualization”, Computers in Industry, Vol. 54, pp. 1-15.

\section{Further reading}

Cross, N. and Cross, A.C. (1995), "Observations of teamwork and social processes in design", Design Studies, Vol. 16 No. 2, pp. 143-70. 


\section{IJPPM \\ Appendix 1 \\ 60,2}

180

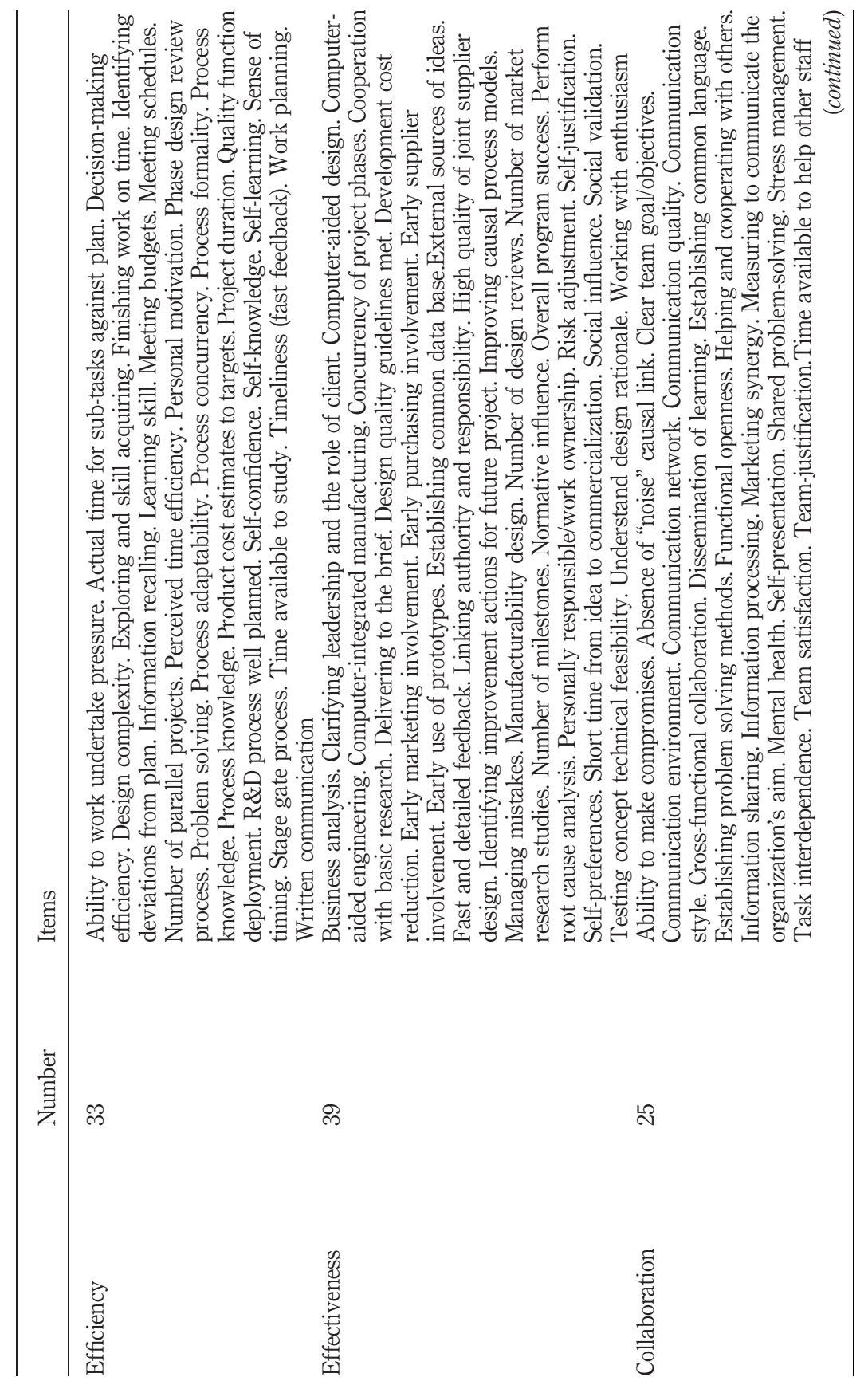

Table AI.

Classified 158 detailed DPM criteria for the five DPM indicators 


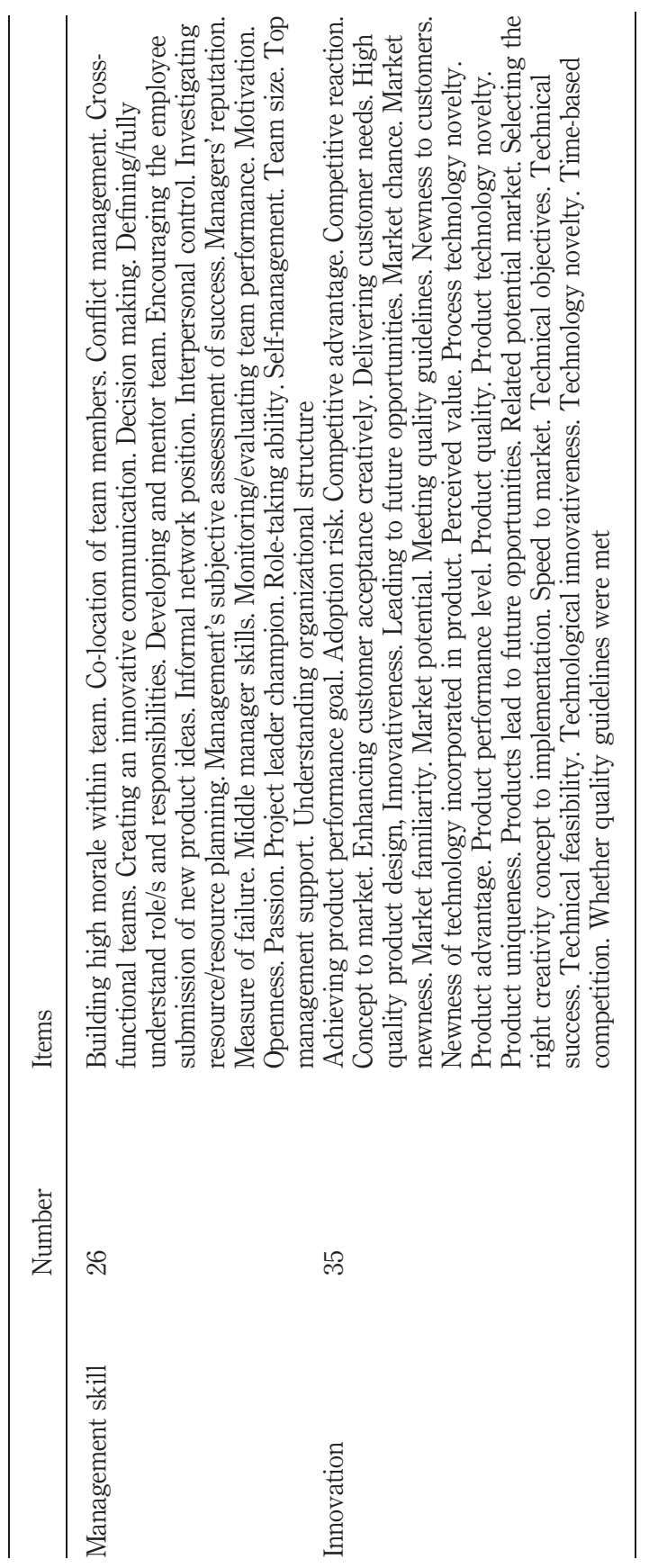

Design
performance
measurement

181

Table AI. 
IJPPM

60,2

182

\section{Appendix 2}

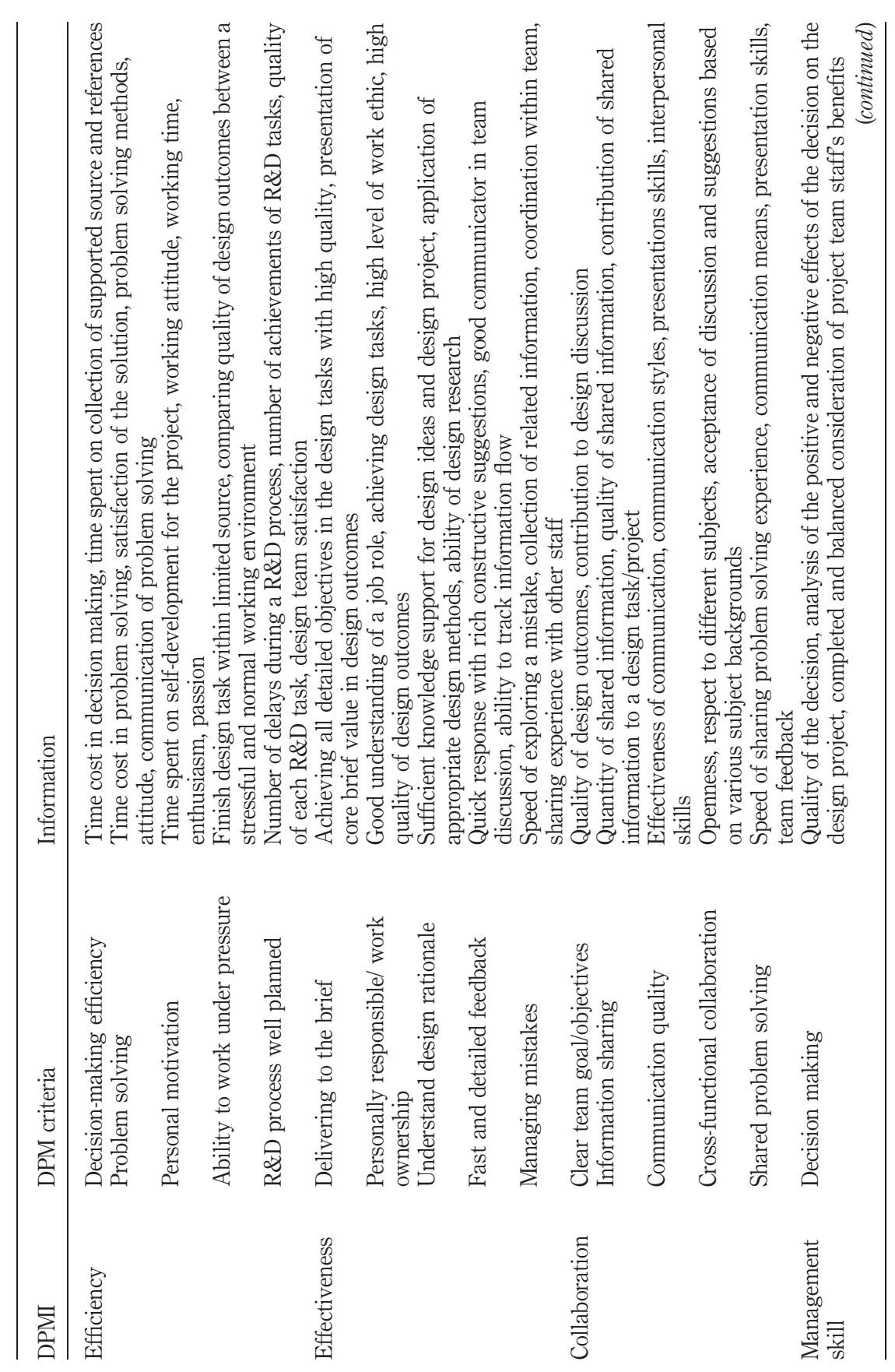

Table AII.

Examples of related information for DPM matrix operation 


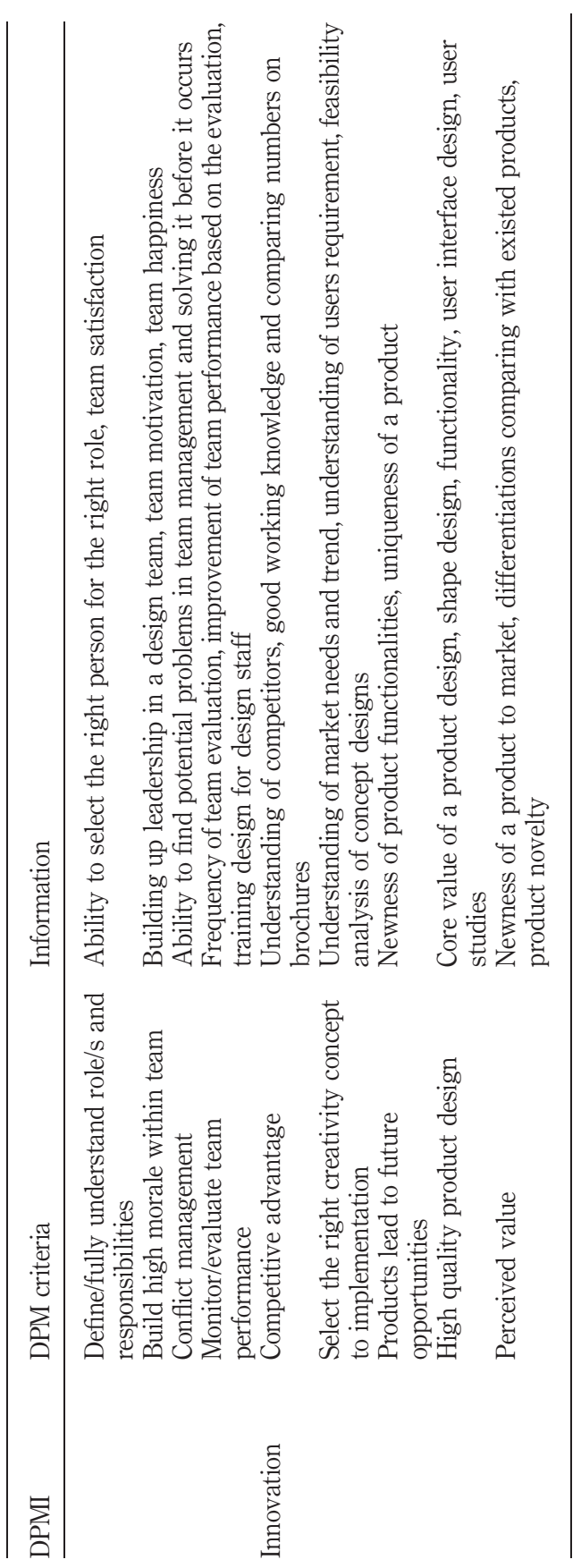

Design performance measurement

183

Table AII. 


\section{IJPPM}

60,2

184

\begin{abstract}
About the authors
Yuanyuan Yin is a Lecturer in Brand Management in the Winchester School of Art, University of Southampton. She obtained her BEng degree in industrial design in China, her MA degree in design strategy \& innovation and $\mathrm{PhD}$ degree in design research from Brunel University, UK. Her research has been concentrated on promoting business performance through developing brand strategies, understanding customers and users, supporting design collaboration, improving product design, integrating design and market trends. She also has in-depth experience working with design industries. Dr Yin is a member of the Design Research Society. Yuanyuan Yin is the corresponding author and can be contacted at: y.yin@soton.ac.uk

Sheng feng Qin is a Senior Lecturer in the School of Engineering and Design, Brunel University, UK. He obtained his BSc and MSc degrees in China and his $\mathrm{PhD}$ degree in CAD from the University of Wales, UK. He was an academic visiting scholar in 1996-1997 at the University of Birmingham. Following this, he took a Research Assistant post in 1998 at the University of Wales Institute Cardiff and subsequently joined Loughborough University as a PostDoc Research Associate in 2000. His research interests include CAD, conceptual design, design management, sketch and visual computing, interaction and interface design. Dr Qin is a member of IEEE and Eurographics.

Ray Holland directs the Masters Design Strategy programmes at Brunel University UK; multi-disciplinary design management courses attracting students from all over the world. Personal research reflects his conviction that design can find its direction through systems thinking and human/cultural issues. He was one of the pioneers of design management education and assists many overseas universities to develop Masters and $\mathrm{PhD}$ programmes in design and branding. He spent his early career as a company lawyer and accountant until he found his home in design. As consultant, Ray has helped to implement large computer-based information systems and design-led change management programmes.
\end{abstract}

To purchase reprints of this article please e-mail: reprints@emeraldinsight.com Or visit our web site for further details: www.emeraldinsight.com/reprints 